\title{
Patrimônio arquitetônico e a história social da saúde brasileira
}

\author{
Architectural heritage and the social history of Brazilian health \\ Patrimonio arquitectónico y la historia social de la salud brasileña
}

\begin{abstract}
HOSPITAIS E SAÚDE NO OITOCENTOS: DIÁLOGOS ENTRE BRASIL E PORTUGAL. Miranda CS, Costa RG-R, organizadores. Rio de Janeiro: Editora Fiocruz; 2018. 223 p. ISBN 978-857541-622-8.
\end{abstract}

doi: 10.1590/0102-311X00111619

A tendência historiográfica de avaliar a independência política brasileira como um processo que favoreceu uma ampla ruptura em relação a Portugal e aos portugueses tem resultado no escasso interesse do estudo do importante papel desempenhado pelos lusitanos que aqui permaneceram, sobretudo no período transcorrido entre o fim do Primeiro Reinado (1831) e o início do movimento imigracionista datado do último quartel do século XIX, quando novas levas de ibéricos chegaram ao país. No entanto, para além dos filtros adotados pela maior parte dos pesquisadores, as influências recíprocas entre Brasil e Portugal sempre foram constantes e só recentemente passaram a ser reavaliadas 1 .

Paralelamente a esse "vício" historiográfico, a história social da medicina brasileira demonstra reticências em adotar a arquitetura hospitalar como uma importante fonte de estudo, tendência que começou a ser revertida nas últimas décadas e que ganhou maior densidade a partir da publicação da coleção História e Patrimônio da Saúde, pela Editora Fiocruz em parceria com a Editora Manole.
O livro Hospitais e Saúde no Oitocentos: Diálogos entre Brasil e Portugal ganha destaque não só por registrar a importância e a continuidade da atuação da comunidade portuguesa no Brasil independente, mas também por dar prosseguimento ao estudo do patrimônio arquitetônico hospitalar. Os méritos da obra não se limitam a isso. A atuação dos engenheiros lusitanos e o papel desempenhado pela Missão Artística Francesa que passou a atuar no Brasil a partir de 1816 são apresentados como elementos disseminadores de uma nova arquitetura cujo modelo constituía-se no estilo neoclássico que a França adotou na edificação ou reforma dos prédios públicos para marcar o período pós 1789. Para os franceses, assim como para os engenheiros-arquitetos brasileiros, as novas construções representavam uma "mudança de espírito" pautada pela apologia de uma nova racionalidade que, por sua vez, instigava os emblemas do progresso, da técnica e, no caso dos hospitais, de uma renovada noção de higiene 2 .

Empolgado em construir seus símbolos arquitetônicos de nação independente, o Brasil buscou imitar o estilo francês, tendo, em boa parte, os engenheiros e os mestres de obra lusitanos como intermediários nessa empreitada, os quais contribuíram para a formação de um contingente nacional de arquitetos nutridos pela estética e pelos ideais neoclássicos. Apesar de as primeiras expressões do movimento neoclássico serem adotadas no Rio de Janeiro logo após a chegada da Família Real Portuguesa à cidade, foi, a partir de 1840 , que ganhou impulso o mo- 
vimento renovador, com a recorrência às novas noções de urbanismo. Nesse cenário, ocorreu a substituição do barroco rococó, que marcara as principais construções do período colonial, pelo neoclassicismo, símbolo da modernidade, caracterizado pela valorização das fachadas, com a recorrência às pilastras gregas e aos ornamentos que comumente faziam alusão aos elos amistosos entre Brasil e Portugal nas platibandas, isto é, nas molduras instaladas na parte superior do edifício para ocultar o telhado para quem observava o prédio. Em conjunto, esses elementos dão sentido ao classicismo imperial brasileiro que, pela ornamentação das platibandas, conferiam uma dimensão nacional ao estilo arquitetônico importado da Europa.

No plano exterior, a construção contava com elementos que atuavam como metáforas dos valores de uma sociedade que se queria liberal, pautada pelo equilíbrio, harmonia e austeridade. No interior dos novos hospitais, mesmo que o edifício fosse acanhado, regia uma lógica espacial que refletia as novas noções de higiene e de finalidades dos ambientes de cura, com paredes azulejadas para facilitar a limpeza, corredores largos que viabilizavam o fluxo de ar e o deslocamento de pessoas e equipamentos. Nesse compasso, o Brasil buscava alcançar sintonia com o contexto político e médico que vigia em alguns países da Europa, sobretudo na França e na Inglaterra: o enlace dos princípios do liberalismo com a redefinição do hospital, que transitou de local onde os pobres recorriam à espera da morte para território de cura regido pela clínica, pela pesquisa e pela formação de novos médicos ${ }^{3}$.

A implantação desse modelo arquitetônico e funcional de hospital também se processou em conformidade com a nova nosologia médica inaugurada pelo francês Bichat. As enfermarias deixaram de ser segmentadas por gênero, mas também pela especificidade das doenças, e, em seguida, foram erguidos hospitais para o acolhimento de portadores de doenças específicas.

No contexto dos artigos que compõem a coletânea enfocada, na qual também desponta, mesmo que acanhadamente, a redefinição das relações entre espaço urbano e as doenças, vêse a evolução paralela da arquitetura neoclássica hospitalar e a multiplicação de unidades nosocomiais, primeiramente no Rio de Janeiro. Na Cor- te, o Hospital Central da Santa Casa, fundado em 1582, foi alvo de intensa reforma para se adaptar ao novo padrão, ao mesmo tempo em que a sociedade criava novos espaços de tratamento. Em 1840, a comunidade lusitana patrocinou a construção do hospital da Real e Benemérita Sociedade Portuguesa de Beneficência, e, em 1865, a Irmandade do Bom Jesus do Calvário colocou em funcionamento um hospital para atender seus filiados, assim como a Ordem Terceira do Carmo, instituída em 1648, construiu um novo hospital em 1864, sendo que a construção anterior foi abandonada por não mais atender às necessidades da medicina do século XIX. No mesmo ritmo, foi erguido o Hospício Pedro II, a primeira unidade nacional especializada no atendimento dos doentes mentais.

O modelo hospitalar implantado no Rio de Janeiro disseminou-se pelo país, sendo destacados, na trama do livro, três estudos que deslocam o centro de interesses para a Região Norte do Brasil. No Pará, beneficiado pelos lucros obtidos com a exploração da borracha desde 1879, Belém modernizou-se, imitando o Rio de Janeiro em vários aspectos, inclusive na arquitetura. A busca pela salubridade incentivou a construção de vários hospitais em estilo neoclássico, dentre eles, o hospital-hospício Juliano Moreira e o hospital D. Luiz I, da Beneficência Portuguesa local.

Uma das novidades trazidas pelo livro constitui-se no fato de o classicismo imperial brasileiro ser transposto para Portugal, especialmente no Município de Fafe, localizado na região norte daquele país. Muitas das construções hospitalares brasileiras do século XIX foram patrocinadas por abastados comerciantes e fazendeiros portugueses que chegaram ao Brasil a partir de 1808 . Parte desse contingente retornou ao país natal a partir de 1850 e, nessas condições, também lá se responsabilizaram pelo erguimento de hospitais, como o Hospital da Misericórdia de Fafe, além de asilos para crianças e sanatórios para tuberculosos. O empenho pela reprodução do mesmo estilo arquitetônico dos nosocômios brasileiros não se manteve integralmente, havendo uma sutil adaptação à sensibilidade portuguesa. Desse movimento resultou o que os lusitanos denominaram de classicismo à brasileira, o qual se diferencia do estilo tupiniquim pela apresentação de platibandas vazadas e com balaústres. No torna-viagem, 
a elite que enriqueceu na antiga colônia importou elementos da arquitetura brasileira, os quais foram também empregados na construção das residências dos endinheirados e nos prédios das unidades fabris que estabeleceram em Portugal.

O Brasil, como nação nova, é frequentemente avaliado exclusivamente como receptáculo das produções culturais da Europa e da África, raramente como um dos polos do diálogo com o estrangeiro, contribuindo com as culturas de outras sociedades. Da mesma forma que Edler 4 anunciou as significativas contribuições dos médicos brasileiros para o esclarecimento das patologias tropicais, enriquecendo os conhecimentos dos pesquisadores europeus do século XIX, também algumas nuanças da arquitetura brasileira influenciaram, em algum grau, o modelo das construções hospitalares portuguesas.

Por fim, resta o alerta sobre o destino desse patrimônio arquitetônico referente à história da saúde nacional. Muitos deles sofreram mutilações no decorrer do século XX e há casos, como o do paraense hospício Juliano Moreira, que a construção foi integralmente destruída em nome de um novo processo modernizador do espaço urbano. Nesse sentido, a obra organizada por Miranda \& Costa fornece informações importantes para o questionamento do destino reservado a esses símbolos materiais do passado no atual contexto sociopolítico brasileiro.

Cláudio Bertolli Filho 1

${ }^{1}$ Faculdade de Arquitetura Artes e Comunicação de Bauru Universidade Estadual Paulista Júlio de Mesquita Filho, Bauru, Brasil.

cbertolli@uol.com.br

\section{Informação adicional}

ORCID: Cláudio Bertolli Filho (0000-0003-35849736).

1. Arruda JJA, Tengarrinha JM. Historiografia luso-brasileira contemporânea. Bauru: Edusc; 1999.

2. Huard P. Sciences, médecine, pharmacie: de la Révolution à L'Empire (1789-1815). Paris: Les Éditions Roger Dacosta; 1970.

3. Starobinski J. História da medicina. Lisboa: Moraes; 1967.

4. Edler FC. A medicina no Brasil imperial: clima, parasitas e patologia tropical. Rio de Janeiro: Editora Fiocruz; 2013. 